\title{
USING TASK-BASED INSTRUCTION IN DESIGNING ENGLISH LEARNING MATERIALS FOR NURSING STUDENTS AT STIK FAMIKA, INDONESIA
}

\author{
Risman Wanci ${ }^{1}$ \\ Sujariati $^{2}$ \\ Sekolah Tinggi Ilmu Keperawatan Famika ${ }^{1}$ \\ Universitas Muhamadiyah Makassar ${ }^{2}$ \\ sapa.rismangmail.com ${ }^{1}$, sujariatiunismuh.ac.id ${ }^{2}$
}

\begin{abstract}
The presentation of appropriate learning materials to students should be an essential concern for a lecturer because some students need the material in general, and there are also those who need it specifically. Accordingly, a lecturer needs to know the needs of the learning materials needed by students who will be taught before the material is given to them. The objectives of this research were to design a syllabus, lesson plan, and coursebook of English for nursing at Nursing College of Famika (STIK Famika), Makassar, Indonesia. A research method used was research and development. It applied five steps of ADDIE design (analyze, design, develop, implement, and evaluate). Qualitative descriptive was used to analyze the data collected. The results of this research recommended a syllabus, lesson plan, and coursebook (English learning materials for nursing students). The coursebook has seven units of learning materials, and the materials were designed based on task-based instruction. The lesson plan was designed after the syllabus design, the important things to be included in the syllabus and lesson plan are learning objectives, standard competence, basic competence, time allotment, indicators, learning materials, learning activities (lecturer and students' activities), method, media, sources to be used, and evaluation. In designing the products (syllabus, lesson plan, and coursebook), the writer involved two lecturers (Nursing and English lecturers) to know their opinions regarding the design of the products. The research results are expected to be useful for the teaching and learning English at the nursing study program of STIK Famika, Makassar, Indonesia.
\end{abstract}

Keywords: Materials Design; English for Nursing; Task-Based Instruction.

\section{INTRODUCTION}

A teacher must implement a proper teaching strategy to establish the improvement of English teaching; it can make the learners feel easy and enjoyable to accept the lesson ${ }^{1}$. Besides having a good strategy, appropriate teaching materials are important as well. A lecturer should also think to have appropriate teaching materials, besides having a great strategy in teaching English ${ }^{2}$. It is important to understand the learning needs in learning because different types of students can have different needs

\footnotetext{
${ }^{1}$ Khadijah Maming, "Helping the EFL Learners in Reading Class: Learning by Interacting with Social Media-Related Topics through Pre-Question Way," Asian EFL Journal 20, no. 11 (2018): $205-23$.

${ }^{2}$ Nirwana Darwis and Risman Wanci, "Students and Lecturers' Perceptions toward the Plan of Nursing English Material Development Based on Needs Analysis," The Asian ESP Journal 15, no. 1.2 (2019): 176-97.
} 
in learning. One of the ways to have appropriate teaching materials is by identifying the learners' needs in learning, and then find a teaching material for the learners. ${ }^{3}$ mentioned English for specific purposes (ESP) is an approach to teach a language with the methods used and the content in teaching are based on the learner's reason for learning. The foundation of English for specific purposes (ESP) is the simple question, why does this learner need to learn a foreign language? This question is important enough to answer before teaching a foreign language. The answer to the question is related to the learner's language needs and learning needs so that the materials given are related to the reason why the student needs to learn a particular language. In addition, as a teacher in determining what to teach and how the best learning material, it is essential to know the needs of the learners ${ }^{4}$.

Regarding the importance of ESP materials for nursing students, the course taught to the students should be based on particular needs analysis. ${ }^{5}$ mentioned the relevance of the English material to the learner's needs would improve their motivation to study and make better and faster in learning the subject. ${ }^{6}$ stated that to improve students' motivation and participation, a language course designed that best suits the learner's interests and needs would contribute to facilitating their learning. In addition, ${ }^{7}$ stated that the design of English for specific purposes (ESP) courses could prepare learners to have professional communication. It is informed that English for specific purposes (ESP) course materials are important in the teaching and learning process, and the needs analysis has an essential role in the ESP course materials development.

Students at Nursing College of Famika (STIK Famika), Makassar, Indonesia, are hoped to be able to communicate in English so that when they are working later, they can communicate among nurses and with their foreign patients. To help the nursing students do this, the materials taught to them should be related to their needs, and the students should have English speaking ability to use in communicating effectively. Communication is an important approach between nurses and patients since it regards the patients' outcomes ${ }^{8}$. Teachers need to design work units and tasks through learning material or media with knowledge of their students and their needs 9 .

Concerning the above explanation, the writers would like to design and develop ESP materials for students at the Nursing College of Famika (STIK Famika), Makassar, Indonesia. It was also supported by the result of previous research about nursing students and lecturers' perceptions toward the plan to develop English teaching materials for nursing students. The previous research findings revealed that based on both mean scores and interview data, both students and lecturers had very high perceptions toward the plan to develop English for nursing based on needs analysis ${ }^{10}$. According to the author, based

\footnotetext{
${ }^{3}$ Hutchinson \& Waters (1987, p. 19)

${ }^{4}$ Syamsul Una, "Needs Analysis of English for Specific Purposes (Development of Economic English Material Based on Shariah Economy System)," Asian EFL Journal 10, no. March (2017): 40-59.

${ }^{5}$ Hutchinson and Waters, English for Specific Purposes: A Learning-Centred Approach.

${ }^{6}$ Josiane Gass, "Needs Analysis and Situational Analysis: Designing an ESP Curriculum for Thai Nurses," English for Specific Purposes World 12, no. 36 (2012).

${ }^{7}$ Gass.

${ }^{8}$ Leila D. Benito, “Communication and Patient Safety: Nurses' Perspective," The Asian ESP Journal 15, no. 1.2 (2019): 57-75.

9 Arifin, Haryanto Atmowardoyo, and Anshari, "Multicultural Approach in Developing Instructional Learning Material at Indonesian Senior High School," in TEFLIN International Conference (Makassar: TEFLIN, 2018), 49-57.

${ }^{10}$ Darwis and Wanci, "Students and Lecturers' Perceptions toward the Plan of Nursing English
} 
on what has been described above, there should be additional nursing English material designed according to the needs of nursing students themselves. To obtain data on these needs, a researcher can also involve nursing students, nursing lecturers, stakeholders, and nurses who work in hospitals.

\section{LITERATURE REVIEW}

ESP prepares materials for target learners to be capable of implementing proper and right English for many goals in the future. Usually, ESP students learn English for doing a particular role, such as for being a flight attendant, mechanic, or doctor. ${ }^{11}$ English for specific purposes (ESP) is a rapprochement or approach to a language teaching in which all determinations as to substance and method are established on the learner's reason for learning ${ }^{12}$. ESP subject is designed for a particular group of language learners' needs in a teaching and learning process of the language and communication skills, or it is designed to have a useful function for the students' professions, study, or workplaces ${ }^{13}$. In addition, needs analysis is defined as a term that covers many aspects, in combining students' aims and backgrounds, their language abilities, their reasons for taking the course, their preferences of teaching and learning, and the situations they will need to communicate in. ${ }^{14}$

English for Specific Purposes (ESP) is a general term that refers to the teaching of English for the learners who have a particular reason to learn the language, whether for getting a job or studying. There are two main areas of ESP: (a) English for Occupational Purposes (EOP) is about how a student is able to use English in a particular job or profession. (b) English for Academic Purposes (EAP), is about how to provide students with the proper language skills for pursuing a tertiary-level course taught in English and/ or presenting, researching, and publishing in an academic setting ${ }^{15}$. The English that a special group of students needs could be taught by knowing what they want in English learning. It can be done by identifying the needs of the students to understand what they want. Let me know what you need English for, then I will let you know the English which you need. ${ }^{16}$

Stated two characteristics of English for specific purposes (ESP), namely absolute and variable characteristics. (1) absolute characteristics: ESP should be designed to meet specific needs of the students; it must use the activities or methodologies that underlie the science they implement; it is concerned with the language parts (grammar, lexis, register), skills, discourse and genres appropriate to these activities. (2) variable characteristics: English for specific purposes (ESP) may be

Material Development Based on Needs Analysis.”

11 Amalia Yahya, Yuyun Ruqiyyat Said, and Masruddin, "Developing Appropriate English Learning Materials for Syariah Economic Law Study Program Students at IAIN Palopo, Indonesia," The Asian ESP Journal 15, no. 1.2 (2019): 22 - 33.

${ }^{12}$ Hutchinson and Waters, English for Specific Purposes: A Learning-Centred Approach.

13 Helen Basturkmen, Developing Courses in English for Specific Purposes (Great Britain: Palgrave Macmillan, 2010).

${ }^{14}$ Ken Hyland, English for Academic Purposes: An Advanced Resource Book (London: Routledge,

${ }^{15}$ Roger Barnard and Dorothy Zemach, "Material for Specific Purposes," in Developing Materials for Language Teaching, ed. Brian Tomlinson (London: An imprint of Bloomsbury Publishing Plc, 2014), 106.

${ }^{16}$ Hutchinson and Waters, English for Specific Purposes: A Learning-Centred Approach. 
related to or designed to specific disciplines; may be used in specific teaching for adult learners, either at a tertiary level institution or in a professional work situation. However, it could be for secondary school learners; It is generally used for intermediate or advanced students; but in most ESP courses, it also discusses basic knowledge of language systems; but it could be implemented for beginners. ${ }^{17}$

Mentioned three types of English for Specific Purposes (ESP): (1) Whereas English is categorized as a restricted language, (2) English is categorized as the language used for academic and work purposes. It is essential enough where someone faced with needs for English in his professional life has particular purposes in learning the language. (3) English with Specific Topic. ${ }^{18}$ ESP was broken down to be three branches: (1) English for Science and Technology (EST), (2) English for Business and Economic (EBE), and (3) English for social studies (ESS). Carver (1983) classified three approaches for ESP: (1) The Approach through Register, (2) The Approach through Discourse, and (2) Study Skills. There are several ways with the purposes to teach skills that the students will need it in learning English skills such as reading flexibility, notetaking, library skills, summarising, etc. In addition, ${ }^{19}$ stated that contributing to the learning process could be in varying ways. The success of education is always linked with the learning process, both the lecturer and students' performance aspects in a classroom. ${ }^{20}$

\section{RESEARCH METHODOLOGY}

This study used development research (R\&D). It is used to design English instructional materials for nursing students based on Task-Based Instruction. There were five steps in developing the material, the five steps based on ADDIE design (Analyze, Design, Develop, Implement, and Evaluate). The steps describe the process applied to instructional design to generate episodes of intentional learning ${ }^{21}$. The participants of this research were 40 nursing students of the nursing study program at STIK Famika, Makassar, Indonesia, in the year of entry 2017. They were involved through a simple random sampling technique based on the reason that the simple random sampling technique is trusted to be representative of the given population. 25 graduate of nursing students were graduates from the nursing department and worked at a Public Hospital in the Indonesian eastern part. The graduates were involved through incidental sampling. 18 nursing lecturers, and 10 stakeholders of Nursing College of Famika (STIK Famika), Makassar, Indonesia. The lecturers and stakeholders were involved through total sampling. There were questionnaires and interviews in doing this research. The questionnaires consisted of needs analysis questionnaires and perception questionnaires. The needs analysis questionnaires were given to students, graduates, lecturers, and stakeholders, while questionnaires of perception were given to students and lecturers

${ }^{17}$ Tony Dudley-Evans and Maggie Jo St John, Developments in English for Specific Purposes: A Multi-Disciplinary Approach (Cambridge: Cambridge University Press, 1998).

${ }^{18}$ Hutchinson and Waters, English for Specific Purposes: A Learning-Centred Approach.

19 Risman Wanci and Nirwana Darwis, "Analyzing In-Service and Pre-Service Teachers' Perceptions on Peer Reflection at IAIN Bone," Asian EFL Journal 23, no. 3.4 (2019): 448-59.

20 David Carver, "Some Propositions About ESP," The ESP Journal 2 (1983): 131-37, https://doi.org/10.1016/0272-2380(93)90003-P.

${ }^{21}$ R. M. Branch, Instrctional Design: The Addie Approach (New York: Springer, 2009). 
only. In the interview section, the writer involved the same respondents in the part of the questionnaires, but not all of them were taken.

\section{RESULTS AND DISCUSSION}

This section shows the results of this research. It describes the designs of the syllabus, lesson plan, and coursebook materials of English for nursing. The products were designed after conducting a needs analysis which involved nursing students, graduates, lecturers, and stakeholders. The needs analysis results informed many things, including the English learning needs and the students' language needs at Nursing College of Famika (STIK Famika), Makassar, Indonesia.

The writer's first thing to be done was to determine the outline and plan to design the products (a syllabus, lesson plan, and coursebook materials of English for nursing for the students at STIK Famika, Makassar, Indonesia). It was done related to the students' learning needs and language needs that informed in the results of the needs analysis that was conducted before the design stage. After that, the writer decided on the objectives, the topics, the content of the materials, which should be included in every unit, and then the learning activities. The learning activities were designed combined with the coursebook content. The materials of the coursebook were designed based on task-based instruction.

Regarding the content of the materials, it is essential to be known that English grammar and four English skills are also included in the content. It was based on the needs analysis results that some respondents suggested to include in the coursebook content the materials of English grammar, daily conversation, reading material, and vocabulary. That's why the coursebook contents also contain the items mentioned.

There are seven units in the coursebook, and the topic of every material is different in every unit. The topic for the first unit is hospital. In this part, it presents material of reading skill with pictures and some tasks to be done by the nursing students, then followed by grammar focus material with some tasks for being done by the students as well, and then followed by writing skill material with some task to do, next listening skill material with some tasks to be done by the students, and the last material in this unit is speaking skill with some tasks for being done by the nursing students. Besides that, it also has a list of vocabulary to be learned and memorized by the students.

The topic for the second unit is admission to a hospital. In this part, it presents useful expressions with some tasks to be done by the nursing students, vocabulary related to hospital rooms. It also has reading skill material, grammar focus material, writing, speaking, and listening skills materials with some tasks for being done by the nursing students when the teaching and learning process is running. Several tasks can be done at home.

The topic for the third unit is self-introduction, and the topic of the next unit is health problems, the next topic is parts of the body, the next topic is asking and giving directions at a hospital, and the topic for the last unit is checking vital signs. The important point to be noticed that every unit has a different topic from others, and it has several materials (reading skill material, grammar focus material, writing material, several vocabulary lists, listening, and speaking skills materials). Besides having different materials in every unit, it also has various tasks in every unit; some tasks were designed to do with a partner, some were designed to do in a group, and some were 
designed to individually. Besides, in the classroom, some tasks can be done at home, or they can be homework.

The syllabus and lesson plan also were designed after getting the needs analysis results data. The lesson plan was designed after designing the syllabus. The writer developed more information in the lesson plan than which was written in the syllabus. The essential things which were included in the syllabus and lesson plan are institution name, department to teach the subject, semester level, subject name, subject code, time allotment, learning objectives, standard competence, basic competence, indicators, learning materials, learning activities (lecturer and students' activities), method, media, sources to be used, and evaluation. In designing the products (syllabus, lesson plan, and coursebook), the writer involved two lecturers (Nursing and English lectures) for asking their opinions concerning the design of the products.

\section{CLOSING}

Based on the results and discussion above, it shows that the products of this research are a syllabus, lesson plan, and coursebook (English learning materials for nursing students). The coursebook has seven units of learning materials, it was designed after collecting needs analysis results, and the coursebook contents were designed based on task-based instruction. The lesson plan was designed after designing the syllabus; the important things to be included in the syllabus and lesson plan are learning objectives, standard competence, basic competence, time allotment, indicators, learning materials, learning activities (lecturer and students' activities), method, media, sources to be used, and evaluation. In designing the products (syllabus, lesson plan, and coursebook), the writer involved two lecturers (Nursing and English lectures) to know their opinions regarding the design of the products. The research results are hoped to be beneficial for the teaching and learning English at nursing study program of STIK Famika, Makassar, Indonesia.

\section{REFERENCES}

Arifin, Haryanto Atmowardoyo, and Anshari. "Multicultural Approach in Developing Instructional Learning Material at Indonesian Senior High School.” In TEFLIN International Conference, 49-57. Makassar: TEFLIN, 2018.

Barnard, Roger, and Dorothy Zemach. "Material for Specific Purposes." In Developing Materials for Language Teaching, edited by Brian Tomlinson, 106. London: An imprint of Bloomsbury Publishing Plc, 2014.

Basturkmen, Helen. Developing Courses in English for Specific Purposes. Great Britain: Palgrave Macmillan, 2010.

Benito, Leila D. “Communication and Patient Safety: Nurses' Perspective." The Asian ESP Journal 15, no. 1.2 (2019): 57-75. 
Branch, R. M. Instrctional Design: The Addie Approach. New York: Springer, 2009.

Carver, David. "Some Propositions About ESP." The ESP Journal 2 (1983): 131-37. https://doi.org/10.1016/0272-2380(93)90003-P.

Darwis, Nirwana, and Risman Wanci. "Students and Lecturers' Perceptions toward the Plan of Nursing English Material Development Based on Needs Analysis." The Asian ESP Journal 15, no. 1.2 (2019): 176-97.

Dudley-Evans, Tony, and Maggie Jo St John. Developments in English for Specific Purposes: A Multi-Disciplinary Approach. Cambridge: Cambridge University Press, 1998.

Gass, Josiane. "Needs Analysis and Situational Analysis: Designing an ESP Curriculum for Thai Nurses." English for Specific Purposes World 12, no. 36 (2012).

Hutchinson, Tom, and Alan Waters. English for Specific Purposes: A Learning-Centred Approach. Cambridge: Cambridge University Press, 1987.

Hyland, Ken. English for Academic Purposes: An Advanced Resource Book. London: Routledge, 2006.

Maming, Khadijah. "Helping the EFL Learners in Reading Class: Learning by Interacting with Social Media-Related Topics through Pre-Question Way." Asian EFL Journal 20, no. 11 (2018): 205-23.

Una, Syamsul. "Needs Analysis of English for Specific Purposes (Development of Economic English Material Based on Shariah Economy System)." Asian EFL Journal 10, no. March (2017): 40-59.

Wanci, Risman, and Nirwana Darwis. "Analyzing In-Service and Pre-Service Teachers' Perceptions on Peer Reflection at IAIN Bone." Asian EFL Journal 23, no. 3.4 (2019): 448-59.

Yahya, Amalia, Yuyun Ruqiyyat Said, and Masruddin. "Developing Appropriate English Learning Materials for Syariah Economic Law Study Program Students at IAIN Palopo, Indonesia." The Asian ESP Journal 15, no. 1.2 (2019): 22 - 33. 